\title{
Effect of Frozen Storage on Physical Properties of Pasta Filata and Nonpasta Filata Mozzarella Cheeses
}

\section{M.-I. Kuo and S. Gunasekaran}

Department of Biological Systems Engineering, 460 Henry Mall,

University of Wisconsin-Madison, Madison, WI 53706

\section{ABSTRACT}

The effects of 1 ) ripening 2,7 , and $14 \mathrm{~d}$ at $7^{\circ} \mathrm{C}$ before freezing; 2) tempering 7 , and $14 \mathrm{~d}$ at $7^{\circ} \mathrm{C}$ after freezing; and 3) frozen storage for 1 and 4 wk at $-20^{\circ} \mathrm{C}$, on the meltability, stretchability, and microstructure of pasta filata and nonpasta filata Mozzarella cheeses were investigated. Cheeses were cut into $5 \times 10 \times 7$ $\mathrm{cm}$ blocks and vacuum-sealed $1 \mathrm{~d}$ after manufacture. The results were compared to the corresponding results obtained with unfrozen control samples, aged at $7^{\circ} \mathrm{C}$ between 2 and $21 \mathrm{~d}$. The changes in physical properties of frozen-stored pasta filata and nonpasta filata Mozzarella cheeses were consistent with critical damage to the cheese microstructure as compared to the unfrozen control samples. Generally, aging before and tempering after freezing resulted in increased meltability of both frozen-stored pasta filata and nonpasta filata Mozzarella cheeses. The stretchability of frozen-stored pasta filata Mozzarella cheese increased during tempering, but that of nonpasta filata Mozzarella cheese decreased during aging and tempering. In most cases, one-week frozen stored pasta filata Mozzarella cheese had higher meltability and stretchability than 4-wk frozen-stored sample. For 1-wk frozenstored nonpasta filata Mozzarella cheese, the meltability increased but stretchability decreased when it was frozen-stored for 4 wk.

(Key words: frozen storage, meltability, Mozzarella cheese, stretchability)

Abbreviation key: FDM = fat in the dry matter, LMPS = low-moisture, part-skim, MNFP = moisture in the nonfat portion, $\mathbf{S E M}=$ scanning electron microscopy.

\section{INTRODUCTION}

Freezing of foods helps to preserve their shelf-life, color, flavor, and nutritive value. However, freezing

Received March 18, 2002.

Accepted October 12, 2002.

Corresponding author: S. Gunasekaran; e-mail: GUNA@facstaff. wisc.edu. also brings about certain physical and organoleptic changes, which may or may not be desirable. Commercially produced cheeses are frozen and stored to decrease the rate of ripening and prolong shelf-life during marketing. There have been several studies on frozen storage of cheese, to ascertain if the cheese can be frozen, how long the frozen cheese can be stored, and what physical and textural changes result.

Initial studies of freezing of cheese were to evaluate the potential damage from freezing during sample transit (Sommer, 1928; McDowall, 1938). Freezing Cheddar cheese at $-18^{\circ} \mathrm{C}$ caused the cheese to become crumbly but the texture was recovered after thawing at normal storage temperature. In the following years, interest in freezing cheese increased as a means of prolonging desirable cheese properties. Morris and Combs (1955) reported that Cheddar cheese could be satisfactorily frozen if cut into one pound or smaller pieces and wrapped in foil. Shannon (1974) observed that frozen Cheddar cheeses had a crumbly body and mealy texture but did not see any significant difference in firmness as measured by a shear test. Luck (1977) noted that high fat content helped cheese to withstand structural changes during frozen storage.

Cervantes et al. (1983) found that there were no statistically significant effects or consistent trends in textural and sensory evaluations of Mozzarella cheese with respect to freezing. Dahlstrom (1980) reported that frozen-thawed cheese evaluated immediately after thawing exhibited an acid flavor, free surface moisture, and poor cohesiveness as compared to the unfrozen cheese. Kasprzak (1992) reported that there were no statistically significant effects on texture, flavor and meltability of Cheddar cheese with respect to freezing and thawing. Oberg et al. (1992b) studied the effects of freezing, thawing, and shredding of low moisture, part-skim (LMPS) Mozzarella cheese on physical properties. They showed that shredded cheese frozen at $-196^{\circ} \mathrm{C}$ stretched the best. However, block cheese frozen at $-20^{\circ} \mathrm{C}$ melted the best.

Diefes et al. (1993) investigated the rheological behavior of frozen and thawed LMPS Mozzarella cheese. Their study showed that the frozen and thawed Mozza- 
Table 1. Composition of pasta filata and nonpasta filata Mozzarella cheeses.

\begin{tabular}{|c|c|c|c|c|c|}
\hline Cheese & MNFP $^{1}$ & $\mathrm{FDM}^{2}$ & Salt & Protein & $\mathrm{pH}$ \\
\hline & & & $(\%)$ & & \\
\hline $\begin{array}{l}\text { LMPS Pasta Filata } \\
\text { Mozzarella } \\
\text { LMPS Nonpasta Filata }\end{array}$ & 60.00 & 41.00 & .32 & 24.87 & 5.37 \\
\hline Mozzarella & 60.63 & 43.02 & 1.88 & 24.56 & 5.02 \\
\hline
\end{tabular}

${ }^{1}$ Moisture in the nonfat portion.

${ }^{2}$ Fat in the dry matter.

${ }^{3}$ Low moisture, part-skim.

rella cheese tested at $20^{\circ} \mathrm{C}$ became harder and more elastic with storage time, while samples stored in a refrigerator became softer and more viscoelastic with time. Upon melting, both 90-d frozen and 90-d refrigerated cheeses were less elastic and viscous than 14-d refrigerated samples. Betola et al. (1996a) evaluated the effects of aging, ripening before or after freezing, and freezing rate on the physical properties of low moisture Mozzarella cheese. From extensive statistical analyses, they concluded that the low moisture Mozzarella cheese could be frozen and then stored at $-20^{\circ} \mathrm{C}$ without loss of quality when aged from 14 to 21 $\mathrm{d}$ at $4^{\circ} \mathrm{C}$ before consumption.

The above studies indicate that freezing, thawing, and frozen storage modify the physical properties of cheeses. However, the specific causes contributing to the changes in cheese physical properties following freezing observed by those studies were not elucidated. Current industry practice is to freeze Mozzarella cheese soon after manufacture, but it is not clear if the timing of freezing and duration of frozen storage currently used in the industry is optimal to ensure desirable physical properties of the cheese. The objectives of this research were to: 1) study the effects of frozen storage, tempering, and aging on physical properties of pasta filata and nonpasta filata Mozzarella cheeses; 2) determine an optimal frozen storage, tempering, and aging combination for these cheeses; and 3 ) investigate the factors contributing to the changes in cheese physical properties.

\section{MATERIALS AND METHODS}

LMPS pasta filata and nonpasta filata Mozzarella cheeses of fairly similar composition (except for salt and $\mathrm{pH}$ ) (Table 1) were manufactured in the Wisconsin Center for Dairy Research pilot plant at the University of Wisconsin-Madison. The make procedures for the cheeses have been described in Kuo et al. (2001).

Eight loaves (each about $2.5 \mathrm{~kg}$ ) of each cheese were cut into 5 -cm $\times 10$-cm $\times 7$-cm blocks. The cheese blocks were vacuum sealed in plastic cheese packing bags
(VF-400, Vilutis \& Co. Inc., Frankfort, IL), divided into four equal groups, and stored in a refrigerator at $7^{\circ} \mathrm{C}$ until the freezing tests. One group was used as a control (unfrozen sample). Each of the other three groups was taken at 2,7 , and $14 \mathrm{~d}$ after manufacture and was frozen and stored at $-21.5^{\circ} \mathrm{C}$ in a conventional freezer. Cheese blocks were removed from the freezer after 1 and $4 \mathrm{wk}$ and then thawed at $7^{\circ} \mathrm{C}$. Thawed cheese blocks were tempered in the refrigerator for 7 and $14 \mathrm{~d}$ before physical property tests. Control cheese samples were stored at $7^{\circ} \mathrm{C}$ and tested at 7,14 , and $21 \mathrm{~d}$.

Temperature profiles of the cheese samples were measured during freezing and thawing using type-T thermocouples connected to a data logger. Thermocouples were inserted into the block samples and positioned at about the center. The ambient temperature was also monitored.

\section{Compositional Analysis}

All compositional analyses were performed in duplicate at $28 \mathrm{~d}$ post-manufacture. The $\mathrm{pH}$ was measured by the gold electrode/quinhydrone method (Case et al., 1985). Salt analysis was performed according to the procedure given by Johnson and Olson (1985) using the chloride analyzer (Model 926, Corning Glass Works, Medfield, MA). Protein concentration was determined by the Kjeldahl method (Case et al., 1985). Moisture was determined by a vacuum oven technique (Case et al., 1985) and fat by the Babcock test (Case et al., 1985). Percentages of fat in the dry matter (FDM) and moisture in the nonfat portion (MNFP) were calculated (Tunick and Shieh, 1995).

\section{Cheese Physical Properties}

Meltability. The UW Meltmeter, a modified squeeze flow apparatus (Wang et al., 1998) was used to measure melting behavior of cheese in triplicate. Cylindrical specimens of cheese, $30-\mathrm{mm}$ diameter and 8-mm height, were cut out with a cork borer and used as described in Kuo et al. (2000). Meltability was calculated as the difference between the initial height and the height of melted cheese at one second.

Stretchability. A uniaxial horizontal test procedure designed and developed by Ak et al. (1993) was modified and used to measure the stretchability of cheese in duplicate. Cheese samples of $38-\mathrm{mm} \times 20$ $\mathrm{mm} \times 6$-mm were put into a sample holder (Figure 1A) and heated in situ to $55^{\circ} \mathrm{C}$ and stretched horizontally in the sample chamber (Figure 1B) using a uniaxial testing device (Instron Model 1130, Instron Corp., Canton, MA) with a 100-N load cell. Crosshead speed 


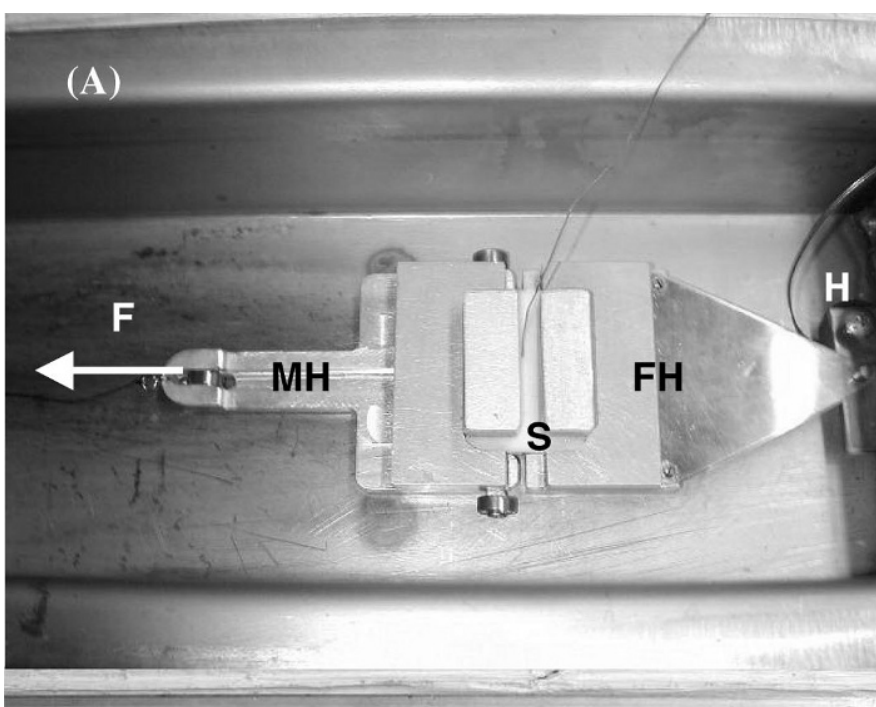

(B)

Figure 1. Uniaxial stretch test, before (A) and after (B) test. (MH = moving holder, $\mathrm{FH}=$ fixed holder, $\mathrm{H}=$ heater, $\mathrm{S}=$ cheese sample, $\mathrm{F}=$ uniaxial force applied).

was set at $21.2 \mathrm{~mm} / \mathrm{s}$. The force required to pull the cheese strings and the length of the strings were obtained from the data. Reciprocal of maximum force was used as an indicator of sample stretchability. The higher the number, the better the stretchability.

\section{Cheese Microstructure}

Scanning electron microscopy (SEM) was used to examine the changes in microstructure of the cheeses. Cheese samples of approximately $1-\mathrm{mm} \times 1-\mathrm{mm} \times 10$ $\mathrm{mm}$, were cut using a razor blade from the interior of the cheese block and immediately fixed in $2.8 \%$ glutaraldehyde in a $0.05 \mathrm{M}$ sodium phosphate buffer ( $\mathrm{pH} 6$ ) for $48 \mathrm{~h}$ at $7^{\circ} \mathrm{C}$. The fixed cheese samples were dehydrated in a graded ethanol series. This consisted of 15 min in each of $25,50,70,80,95,100,100$, and $100 \%$ (v/v) ethanol solution. The samples were then defatted three times with chloroform for $15 \mathrm{~min}$. The defatted samples were dehydrated three times with absolute ethanol for $15 \mathrm{~min}$. Samples were then frozen in liquid nitrogen and fractured. The frozen and fractured samples were thawed in 100\% ethanol and critical point dried with liquid carbon dioxide using a Samdri 780A critical-point-drier (Tousimis Research Co., Rockville, MD). The dried, fractured cheese samples were mounted on aluminum SEM stubs using a carbonbased tape and coated with gold in a DC sputter coater (Seevac Auto Conductavac IV, Seevac Inc., Pittsburgh, PA). The samples were examined in a Hitachi S-570 $\mathrm{LaB}_{6}$ scanning electron microscope operated at an accelerating voltage of $10 \mathrm{kV}$.

\section{Statistical Analysis}

The data from the measurement of physical properties were subjected to ANOVA using the GLM procedure of SAS (SAS, Version 6, Cary, NC, 1989). The statistical model employed was: $\mathrm{Y}_{\mathrm{ijkl}}=\mu+\mathrm{A}_{\mathrm{i}}+\mathrm{F}_{\mathrm{j}}+\mathrm{T}_{\mathrm{k}}$ $+(\mathrm{A} \times \mathrm{F})_{\mathrm{ij}}+(\mathrm{A} \times \mathrm{T})_{\mathrm{ik}}+(\mathrm{F} \times \mathrm{T})_{\mathrm{jk}}+(\mathrm{A} \times \mathrm{F} \times \mathrm{T})_{\mathrm{ijk}}+\varepsilon_{\mathrm{ijkl}}$ where, $\mathrm{Y}=$ cheese physical properties, $\mu=$ reference, $\mathrm{A}=$ effect of aging ( $\mathrm{i}=1$ to 3 ), $\mathrm{F}=$ effect of frozen storage ( $\mathrm{j}=1$ to 2 ), $\mathrm{T}=$ effect of tempering ( $\mathrm{k}=1$ to 2 ), $\mathrm{A} \times \mathrm{F}=$ effect of aging by frozen storage interaction, $\mathrm{A} \times \mathrm{T}=$ effect of aging by tempering interaction, $\mathrm{F} \times$ $\mathrm{T}=$ effect of frozen storage by tempering interaction, $\mathrm{A}$ $\times \mathrm{F} \times \mathrm{T}=$ effect of aging by frozen storage by tempering interaction, and $\varepsilon_{\mathrm{ijkl}}=$ residual variation. Significant interaction and main effects were compared using Fisher's Protected LSD. A test was described as significant only when $P<0.05$.

\section{RESULTS AND DISCUSSION}

\section{Freeze-Thaw Temperature Profiles}

The temperature profiles of pasta filata and nonpasta filata Mozzarella cheese samples during freezing at $-21.5^{\circ} \mathrm{C}$ and thawing at $7^{\circ} \mathrm{C}$ are presented in Figure 2. Characteristic supercooling was clearly noticeable in the temperature profile of the pasta filata Mozzarella cheese sample. The temperature profiles of both cheeses during freezing were similar except for the initial freezing point. As expected, thawing of both pasta filata and nonpasta filata Mozzarella cheese samples was slower than freezing. This is due to the higher thermal resistance of water, compared to ice, in the outer layers of cheese during thawing.

The initial freezing points of pasta filata and nonpasta filata Mozzarella cheese samples were $-0.84^{\circ} \mathrm{C}$ and $-2.37^{\circ} \mathrm{C}$, respectively. The lower initial freezing point of nonpasta filata Mozzarella cheese sample may 


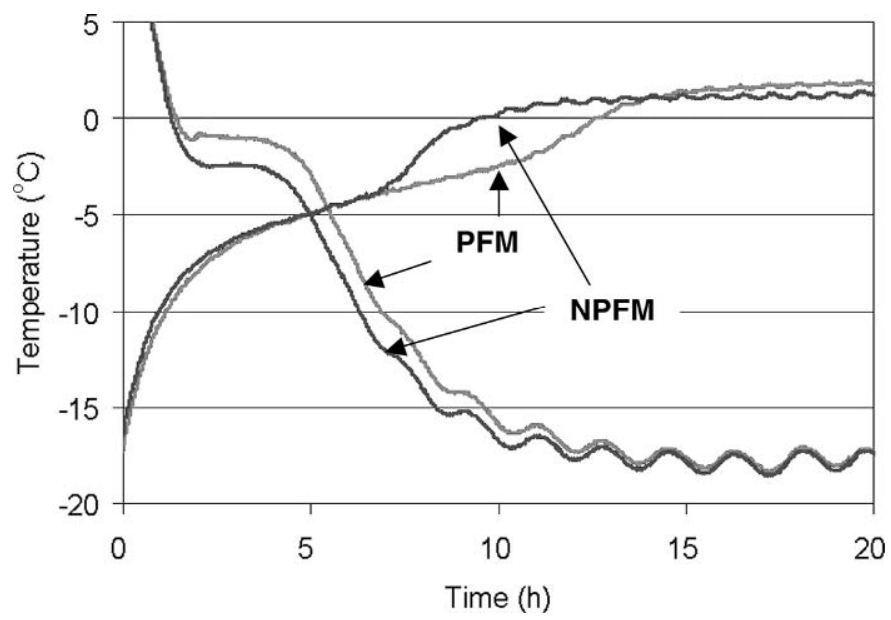

Figure 2. Temperature profiles of pasta filata Mozzarella (PFM) and nonpasta filata Mozzarella (NPFM) cheeses during freezing and thawing.

be due to higher salt content than that of the pasta filata Mozzarella cheese sample (Table 1). The effect of lower $\mathrm{pH}$ of non pasta filata Mozzarella cheese on the initial freezing point is not clear. Dahlstrom (1980) reported similar relationships for initial freezing point, salt concentrations, and $\mathrm{pH}$ of LMPS Mozzarella cheese.

\section{Cheese Physical Properties}

Refrigerated cheese (control samples). The physical properties of control pasta-filata and nonpasta filata Mozzarella cheeses during 21-d storage are shown in Table 2. Aging had a significant effect on meltability and stretchability of LMPS pasta filata and nonpasta filata Mozzarella cheeses stored at $7^{\circ} \mathrm{C}$. The meltability of pasta filata Mozzarella cheese increased gradually during the $3 \mathrm{wk}$ of storage. The increase in meltability of nonpasta filata Mozzarella

Table 2. Effect of aging on physical properties of control LMPS pasta filata and nonpasta filata Mozzarella cheeses stored at $7^{\circ} \mathrm{C}$.

\begin{tabular}{lll}
\hline $\begin{array}{l}\text { Age } \\
(\mathrm{d})\end{array}$ & $\begin{array}{l}\text { Meltability } \\
(\mathrm{mm})\end{array}$ & $\begin{array}{l}\text { Stretchability } \\
(1 / \mathrm{N})\end{array}$ \\
\hline $\begin{array}{l}\text { Pasta Filata Mozzarella } \\
7\end{array}$ & $1.39^{\mathrm{a}}$ & \\
14 & $1.45^{\mathrm{b}}$ & $0.83^{\mathrm{a}}$ \\
21 & $1.72^{\mathrm{c}}$ & $1.20^{\mathrm{b}}$ \\
Nonpasta Filata Mozzarella & & \\
7 & $1.23^{\mathrm{a}}$ & $0.76^{\mathrm{a}}$ \\
14 & $1.41^{\mathrm{b}}$ & $0.93^{\mathrm{b}}$ \\
21 & $2.27^{\mathrm{c}}$ & $1.03^{\mathrm{b}}$ \\
\hline
\end{tabular}

a,b,c Different letters indicate significance $(P<0.05)$ between the mean values of each physical property within each cheese. cheese from 7 to $14 \mathrm{~d}$ was smaller than that from 14 to $21 \mathrm{~d}$.

There was a significant increase $(P<0.05)$ in stretchability of pasta filata Mozzarella cheese from 7 to 14 $\mathrm{d}$ but no significant change was observed from 14 to 21 d. However, an inverse relationship between stretchability and meltability of Mozzarella cheese has been reported (Keller et al., 1974; Oberg et al., 1991a; Oberg et al., 1992a; 1992b). In this study, the cheese with greater stretchability had the higher meltability. Similar changes in stretchability were found in nonpasta filata Mozzarella cheese during aging. Changes in physical properties of pasta filata and nonpasta filata Mozzarella cheeses during storage might be attributed to the breakdown of $\alpha_{\mathrm{s} 1}$-casein and $\beta$-casein in cheese by residual coagulant and milk plasmin (Farkye et al., 1991), the changes in the state of water in cheese (Kuo, 2001), and the increase in protein hydration sphere of cheese (McMahon et al., 1999; Kuo et al., 2001).

Frozen Cheese. Effects of frozen storage and tempering on the physical properties of LMPS pasta filata and nonpasta filata Mozzarella cheeses of three aging periods before frozen storage are shown in Figure 3. Meltability of frozen-stored pasta filata Mozzarella cheese sample increased as the aging increased from 2 to $14 \mathrm{~d}$. The effect was pronounced for 1-wk frozenstored sample as evidenced by the significant $(P<0.05)$ age $\times$ frozen storage interaction (Table 3 ). Further tempering of frozen-stored samples resulted in increased meltability, but only the samples aged 2 and $14 \mathrm{~d}$ before frozen storage showed significant differences $(P<$ $0.05)$. The effect was the same whether the duration of frozen storage was short or long, resulting in insignificant $(P>0.05)$ frozen storage $\times$ tempering interaction (Table 3). The meltability of 1-wk frozen-stored cheese sample was similar to that frozen-stored for 4 wk. However, when the cheese sample was aged for $14 \mathrm{~d}$ before freezing then the meltability was higher for the sample stored frozen for $1 \mathrm{wk}$ compared to $4 \mathrm{wk}$.

Generally, there was no significant change in meltability of frozen-stored nonpasta filata Mozzarella cheese sample aged from 2 to $7 \mathrm{~d}$, but a significant increase in meltability of frozen-stored cheese sample aged from 7 to $14 \mathrm{~d}$ was observed. The increased meltability in cheese from 2 to $14 \mathrm{~d}$ was the same whether the frozen storage was short or long, as evidenced by the insignificant $(P>0.05)$ age $\times$ frozen storage interaction (Table 4). Longer tempering of the frozen-stored cheese sample increased the meltability of both 1- and 4 -wk frozen-stored samples aged 2 and $14 \mathrm{~d}$ before frozen storage and no significant change in the sample aged $7 \mathrm{~d}$ before frozen storage, resulting in insignificant $(P>0.05)$ frozen storage $\times$ tempering interaction 


\section{Meltability of Pasta Filata Mozzarella}
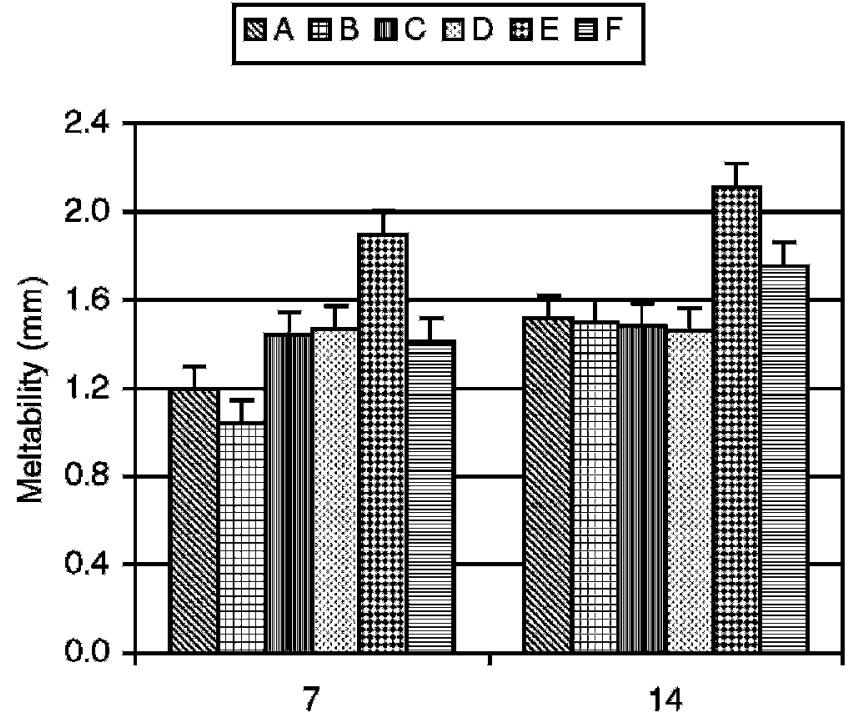

Meltability of Non-pasta Filata Mozzarella

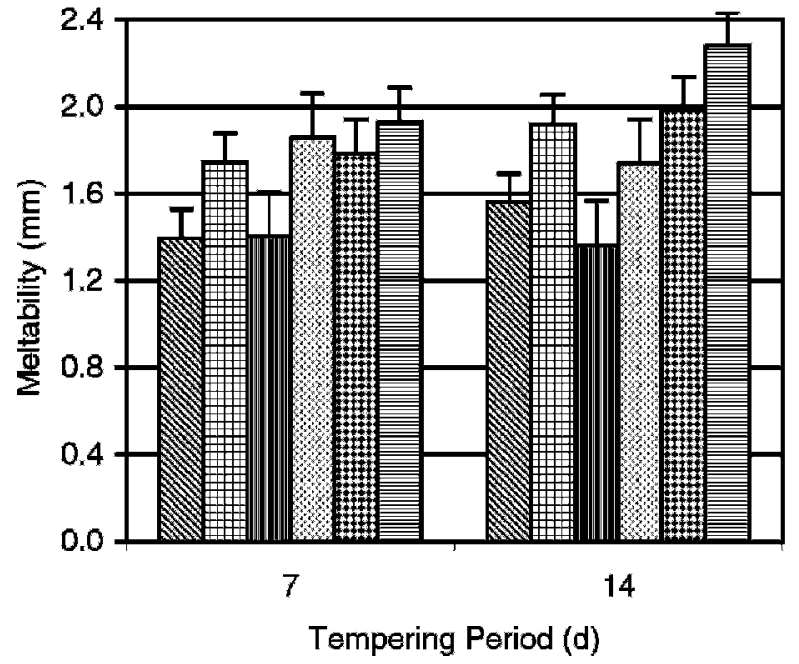

\section{Stretchability of Pasta Filata Mozzarella}

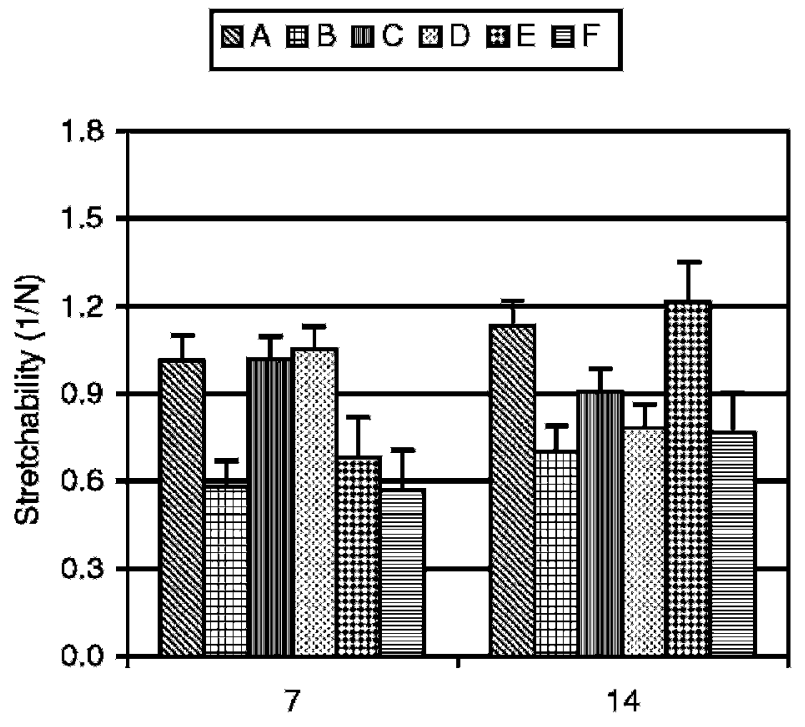

\section{Stretchability of Non-pasta Filata Mozzarella}

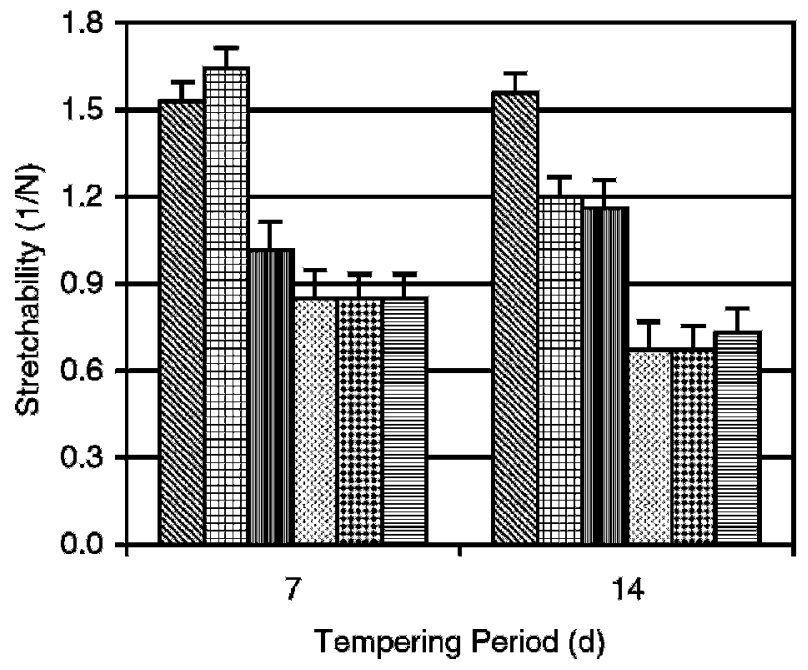

Figure 3. Effect of frozen storage, aging, (before frozen storage) and tempering, (after frozen storage) on the meltability and stretchability of pasta filata and nonpasta filata Mozzarella cheeses. $(\mathrm{A}=2$-d aging and 1-wk frozen storage, $\mathrm{B}=2$ - $\mathrm{d}$ aging and 4-wk frozen storage, $\mathrm{C}=$ 7-d aging and 1-wk frozen storage, $\mathrm{D}=7$-d aging and 4-wk frozen storage, $\mathrm{E}=14$-d aging and 1-wk frozen storage, $\mathrm{F}=14$ - $\mathrm{d}$ aging and 4wk frozen storage). The 5\% LSD is indicated by the error bars.

(Table 4). Cheese samples stored frozen for $1 \mathrm{wk}$ had a lower meltability than those stored for $4 \mathrm{wk}$.

Proteolysis has been correlated with changes in the melt properties of Mozzarella cheeses (Oberg et al., 1991a; 1991b). Protein breakdown in Mozzarella cheese as a result of residual coagulant and milk plas- min breakdown of $\alpha_{\mathrm{s} 1}$-casein and $\beta$-casein (Tunick et al., 1993) reduced cohesiveness and softened the body, thus increasing meltability (Oberg et al., 1992b). Accordingly, the effect of aging and tempering on the meltability of both frozen-stored pasta filata and nonpasta filata Mozzarella cheeses might be due to prote- 
Table 3. Effect of experimental variables on physical properties-statistical analysis of LMPS pasta filata Mozzarella.

\begin{tabular}{|c|c|c|c|c|c|c|}
\hline \multirow[b]{2}{*}{ Source of variation } & \multicolumn{3}{|c|}{ Meltability } & \multicolumn{3}{|c|}{ Stretchability } \\
\hline & $\mathrm{df}$ & $\mathrm{F}$ & $\mathrm{P}$ & $\mathrm{df}$ & $\mathrm{F}$ & $\mathrm{P}$ \\
\hline Age (A) & 2 & 81.56 & $<0.0001$ & 2 & 10.12 & 0.0027 \\
\hline Frozen Storage (FS) & 1 & 28.98 & $<0.0001$ & 1 & 101.81 & $<0.0001$ \\
\hline Temper $(\mathrm{T})$ & 1 & 52.11 & $<0.0001$ & 1 & 15.22 & 0.0021 \\
\hline $\mathrm{A} \times \mathrm{FS}$ & 2 & 16.92 & $<0.0001$ & 2 & 21.01 & 0.0001 \\
\hline $\mathrm{A} \times \mathrm{T}$ & 2 & 12.32 & 0.0002 & 2 & 41.95 & $<0.0001$ \\
\hline $\mathrm{FS} \times \mathrm{T}$ & 1 & 1.16 & 0.2923 & 1 & 11.31 & 0.0056 \\
\hline $\mathrm{A} \times \mathrm{FS} \times \mathrm{T}$ & 2 & 0.88 & 0.4297 & 2 & 3.48 & 0.0643 \\
\hline Error & 24 & & & 12 & & \\
\hline Corrected Total & 35 & & & 23 & & \\
\hline
\end{tabular}

olysis of the protein matrix during refrigerated storage.

Stretchability of frozen-stored pasta filata Mozzarella cheese samples aged 2 and $14 \mathrm{~d}$ before frozen storage increased with tempering time, but that of samples aged $7 \mathrm{~d}$ before frozen storage decreased with tempering time. The effect was more pronounced for the 1-wk frozen-stored samples, resulting in significant $(P<0.05)$ frozen storage $\times$ tempering interaction (Table 3). Generally, cheese samples stored frozen for 1 wk had a higher stretchability than 4 -wk frozenstored samples.

Stretchability of frozen-stored nonpasta filata Mozzarella cheese samples decreased during aging from 2 to $14 \mathrm{~d}$. The effect is more pronounced for 1-wk frozenstored cheese samples, as evidenced by the significant $(P<0.05)$ age $\times$ frozen storage interaction (Table 4$)$. Stretchability of 4-wk frozen-stored samples decreased significantly during tempering, while stretchability of 1-wk frozen-stored samples aged $7 \mathrm{~d}$ before frozen storage increased and sample aged $14 \mathrm{~d}$ before frozen storage decreased during tempering, leading to a significant frozen storage $\times$ tempering interaction (Table 4 ).

Harvey et al. (1982) stated that meltability might be related to the state of casein in the cheese and extent of proteolysis. Diefes et al. (1993) mentioned that local dehydration of proteins causes breaks in protein structure as cheese undergoes freezing. Bertola et al. (1996b) speculated that the protein network in cheese weakened by freezing is more susceptible to proteolysis. Fontecha et al. $(1993 ; 1996)$ reported the conversion of $\alpha$-helix and $\beta$-(sheet or strand) structures of the casein in frozen ewe's milk cheese in to unordered structure, particularly in slowly frozen samples, consistent with greater damage to the microstructure observed by SEM and greater proteolysis. The investigations on the effects of freezing on cheese microstructure are few (Fontecha et al., 1996; Perez-Munuera et al., 1999) and none pertinent to Mozzarella cheese were found.

\section{Cheese Microstructure}

A large portion of the reticular structure of the unfrozen pasta filata Mozzarella cheese (Figure 4A) was damaged and the protein matrix became more porous in the frozen-stored pasta filata Mozzarella cheese sample (Figures 4B and 4C). Local dehydration of proteins and ice crystal formation in cheese during freezing and frozen storage might cause breaks in the protein structure (Diefes et al., 1993). Extended frozen storage might result in a more extensive breakdown

Table 4. Effect of experimental variables on physical properties-statistical analysis of LMPS nonpasta filata Mozzarella.

\begin{tabular}{|c|c|c|c|c|c|c|}
\hline \multirow[b]{2}{*}{ Source of variation } & \multicolumn{3}{|c|}{ Meltability } & \multicolumn{3}{|c|}{ Stretchability } \\
\hline & $\mathrm{df}$ & $\mathrm{F}$ & $\mathrm{P}$ & $\mathrm{df}$ & $\mathrm{F}$ & $\mathrm{P}$ \\
\hline Age (A) & 2 & 17.02 & $<0.0001$ & 2 & 129.53 & $<0.0001$ \\
\hline Frozen Storage (FS) & 1 & 29.95 & $<0.0001$ & 1 & 13.90 & 0.0029 \\
\hline Temper $(\mathrm{T})$ & 1 & 3.98 & 0.0575 & 1 & 11.10 & 0.0060 \\
\hline $\mathrm{A} \times \mathrm{FS}$ & 2 & 0.83 & 0.4489 & 2 & 7.42 & 0.0080 \\
\hline $\mathrm{A} \times \mathrm{T}$ & 2 & 2.99 & 0.0695 & 2 & 2.23 & 0.1499 \\
\hline $\mathrm{FS} \times \mathrm{T}$ & 1 & 0.07 & 0.8000 & 1 & 10.23 & 0.0077 \\
\hline $\mathrm{A} \times \mathrm{FS} \times \mathrm{T}$ & 2 & 0.33 & 0.7215 & 2 & 4.18 & 0.0418 \\
\hline Error & 24 & & & 12 & & \\
\hline Corrected Total & 35 & & & 23 & & \\
\hline
\end{tabular}



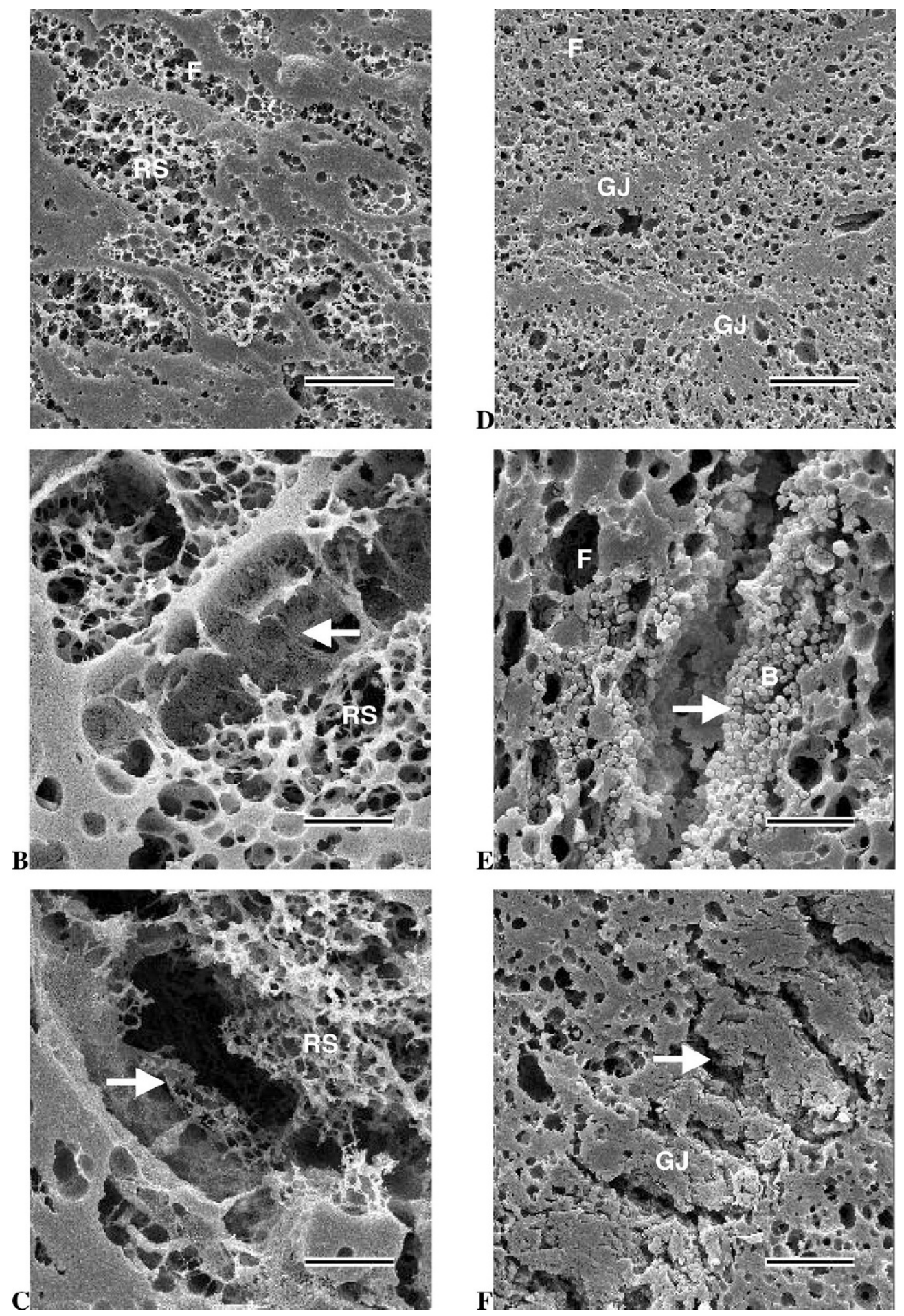

Figure 4. Scanning electron micrographs of (A, B, and C) pasta filata Mozzarella cheese and (D, E, and F) nonpasta filata Mozzarella cheese. (A) Unfrozen pasta filata Mozzarella cheese sample (aged 14 d). (B) Frozen-stored pasta filata Mozzarella cheese sample (aged 2 d, frozen-stored $4 \mathrm{wk}$ ), arrow indicates the porosity of protein matrix. (C) Frozen-stored pasta filata Mozzarella cheese sample (aged $7 \mathrm{~d}$, frozenstored $1 \mathrm{wk}$ ), arrow indicates the breakdown of reticular structure. (D) Unfrozen nonpasta filata Mozzarella cheese sample (aged $14 \mathrm{~d}$ ). (E) Frozen-stored nonpasta filata Mozzarella cheese sample (aged 2 d, frozen-stored 1 wk), arrow indicates clumps of bacteria. (F) Frozen-stored nonpasta filata Mozzarella cheese sample (aged $14 \mathrm{~d}$, frozen-stored $4 \mathrm{wk}$ ), arrow indicates cracks. $(\mathrm{RS}=$ reticular structure, GJ = granule junction, $\mathrm{F}$ = location of fat globule, $\mathrm{B}$ = bacteria). Scale bars represent: A-20 $\mu \mathrm{m}, \mathrm{B}-8 \mu \mathrm{m}, \mathrm{C}-8 \mu \mathrm{m}, \mathrm{D}-40 \mu \mathrm{m}, \mathrm{E}-8 \mu \mathrm{m}$, and F-20 $\mu \mathrm{m}$. 
of the cheese structure due to recrystallization of melted ice crystals. Upon tempering, the proteins are unable to fully rebind water (Diefes et al., 1993). Kuo (2001) reported that water is less confined to the protein matrix as evidenced by a sharp increase in water self-diffusion coefficient of frozen-stored pasta filata Mozzarella cheese sample as compare to the unfrozen sample. These pools of water might then lead to a more porous protein matrix in frozen-stored cheese samples.

We presume that damage to the cheese structure caused by freezing and frozen storage and partial rehydration of the protein matrix are the dominant factors leading to the changes in the physical properties of pasta filata Mozzarella cheese sample. Partial rehydration of the protein matrix might be less pronounced for the 4-wk frozen-stored cheese sample due to a more extensive breakdown of the cheese structure. It is doubtful if tempering of pasta filata Mozzarella would cause full recovery of cheese physical properties.

The frozen-stored nonpasta filata Mozzarella cheese samples contained noticeable clumps of bacteria, about $0.8 \mu \mathrm{m}$ in diameter (Figure $4 \mathrm{E}$ ), which were not observed in the unfrozen sample (Figure 4D), resulting in the formation of cracks in the cheese sample. We postulate that the distribution of bacteria in nonpasta filata Mozzarella cheese samples was uneven. Upon frozen storage, the local cheese matrix where those bacteria are embedded might be more susceptible to damage. This observation can be made because there were clumps of granule-like bacteria in several areas in the frozen-stored cheese samples. The presence of numerous clumps of granule-like bacteria may present local discontinuities in the cheese matrix structure upon frozen storage. Cracks were also observed in the curd granule junctions of frozen-stored nonpasta filata Mozzarella cheese sample (Figure 4F). Fontecha et al. (1996) suggested that ruptures in the curd granule junctions of cheese sample may be attributed either to ice crystal formation, or as a result of stresses in the matrix due to immobilization of the aqueous phase by freezing while the ice expands which results in cracks.

The areas where the cracks and the granule-like bacteria clusters are present may weaken the protein network, and consequently change the physical properties of the cheese sample. Extended frozen storage critically damages the cheese matrix (Fontecha et al., 1996), leading to increased meltability of the cheese sample frozen stored for $4 \mathrm{wk}$ compared to $1 \mathrm{wk}$ for nonpasta filata Mozzarella cheese.

\section{Comparisons of Studied Factors}

It has been reported that the most critical temperature range in terms of harming cheese quality due to the formation of ice crystals is $\pm 2{ }^{\circ} \mathrm{C}$ surrounding the initial freezing point (Price, 1935). The more rapidly cheese passes through this freezing zone, the less damage is done to the cheese microstructure and consequently less change to the cheese physical properties. Temperature fluctuation of cheese samples caused by freezer defrost cycle during frozen storage as shown in Figure 2 might have resulted in recrystallization of melted ice crystals leading to some changes in cheese microstructure.

Kuo et al. (2001) reported that water-holding capacity of pasta filata Mozzarella cheese stored at $7^{\circ} \mathrm{C}$ increases from d 2 to 10 . Water in pasta filata Mozzarella cheese exists in the fat-serum channel and is absorbed by the protein matrix during the early stages of maturation. This is accompanied by a swelling of the protein matrix that continues until the spaces between the fat globules are completely filled by the protein matrix (McMahon et al., 1999) as evidenced by the formation of a reticular structure in Figure 4A. It may be presumed that a considerable amount of the water molecules in 7-d aged cheese are absorbed by the protein matrix, thus, the protein fibers suffer minor damage due to small ice crystals in the cheese matrix. During tempering, the remainder of the water molecules in cavities continuously migrate into the protein matrix as evidenced by the formation of new reticular structures in the localized area within the matrix (Kuo, 2001). Combining the observations of McMahon et al. (1999), Kuo et al. (2001), and the results presented in this study, it may be concluded that pasta filata Mozzarella should be aged 1 wk at $7^{\circ} \mathrm{C}$ before freezing and can be stored for $4 \mathrm{wk}$ at $-20^{\circ} \mathrm{C}$ to obtain good melt and stretch properties of the cheese as long as the final product is tempered for $7 \mathrm{~d}$ before consumption. In this case, minor damage to the protein matrix in cheese would not change the cheese physical properties to an extent that it is unacceptable to consumers.

Freezing and frozen storage of nonpasta filata Mozzarella cheese sample damaged the protein matrix structure at localized areas as evidenced by the formation of cracks and clumps of bacteria. Filchacova et al. (1983) reported that alterations in the structure of the protein matrix during freezing results in partial separation of the free water as evidenced by a lower water-holding capacity. Kuo (2001) observed a lower water self-diffusion coefficient in frozen-thawed cheese sample tempered for $7 \mathrm{~d}$ compared to $1 \mathrm{~d}$, indicating that tempering might cause partial rebinding of water into the protein matrix. Thus, nonpasta filata Mozzarella could be frozen soon after manufacture (e.g., $2 \mathrm{~d}$ postmanufacture), but the cheese has to be tempered at least a week. However, prolonging the tempering period might result in extensive proteolysis 
of cheese and adversely affect its physical properties. Accordingly, to retain good melt and stretch properties, nonpasta filata Mozzarella can be stored up to 4 wk at $-20^{\circ} \mathrm{C}$ as long as the product is aged at $7^{\circ} \mathrm{C}$ for a total (before and after frozen storage) of 9 to $16 \mathrm{~d}$.

\section{CONCLUSIONS}

Effect of frozen storage on physical properties of pasta filata and nonpasta filata Mozzarella cheeses was different probably due to different microstructure. Extended frozen storage might result in a more extensive change in cheese physical properties. Aging and tempering of cheeses before and after frozen storage are necessary to mitigate damage to the protein matrix. Thus, pasta filata Mozzarella should be aged 1 wk at $7^{\circ} \mathrm{C}$ before freezing and can be stored for $4 \mathrm{wk}$ at $-20^{\circ} \mathrm{C}$ to obtain good melt and stretch properties of the cheese as long as the final product is tempered for $7 \mathrm{~d}$ before consumption. Nonpasta filata Mozzarella can be stored up to $4 \mathrm{wk}$ at $-20^{\circ} \mathrm{C}$ as long as the product is aged and tempered at $7^{\circ} \mathrm{C}$ for a total of 9 to $16 \mathrm{~d}$.

\section{ACKNOWLEDGMENTS}

The authors thank Dr. Philip Oshel for skillful technical assistance on scanning electron microscope and useful suggestions. Appreciation is expressed to Dr. Ralph Albrecht for valuable discussions. The authors acknowledge access to the Hitachi S-570 $\mathrm{LaB}_{6}$ scanning electron microscope made available by the Biological and Biomaterials Preparation, Imaging, and Characterization Laboratory at the Department of Animal Sciences in the University of Wisconsin-Madison. This research was founded by a grant from Dairy Management, Inc.

\section{REFERENCES}

Ak, M. M., D. Bogenrief, S. Gunasekaran, and N. F. Olson. 1993. Elongational properties of Mozzarella cheese by horizontal uniaxial extension tests. J. Texture Studies 24:437-453.

Bertola, N. C., A. N. Califano, A. E. Bevilacqua, and N. E. Zaritzky. 1996a. Effect of freezing conditions on functional properties of low moisture Mozzarella cheese. J. Dairy Sci. 29:185-190.

Bertola, N. C., A. N. Califano, A. E. Bevilacqua, and N. E. Zaritzky. 1996b. Textural changes and proteolysis of low-moisture Mozzarella cheese frozen under various conditions. Lebensmittel-Wissenchaft and Technologie. 29:470-474.

Case, R. A., R. L. Bradley, Jr., and R. R. Williams. 1985. Chemical and physical methods. Page 327-404 in Standard Methods for the Examination of Dairy Products. G. H. Richardson. 15th ed. Am. Publ. Health Assoc., Inc., Washington, DC.

Cervantes, M. A., D. B. Lund, and N. F. Olson. 1983. Effects of salt concentration and freezing on Mozzarella cheese texture. J. Dairy Sci. 66:204-213.
Dahlstrom, D. G. 1980. Frozen storage of low moisture, part-skim Mozzarella cheese. M.S. Thesis, Univ. Wisconsin, Madison.

Diefes, H. A., S. S. H. Rizvi, and J. A. Bartsch. 1993. Rheological behavior of frozen and thawed low-moisture, part-skim Mozzarella cheese. J. Food Sci. 58:764-769.

Farkye, N. Y., L. J. Kiely, R. D. Allshouse, and P. S. Kindstedt. 1991. Proteolysis in Mozzarella cheese during refrigerated storage. J. Dairy Sci. 74:1433-1438.

Filchacova, N., R. I. Pankova, Z. A. Mishenina, and G. Ovcharova. 1983. Changes of protein properties during freezing. Page 502506 in XVI International Congress of Refrigeration. International Institute of Refrigeration, Paris.

Fontecha, J., J. Bellanato, and M. Juarez. 1993. Infrared and Raman spectroscopic study of casein in cheese: Effect of freezing and frozen storage. J. Dairy Sci. 76:3303-3309.

Fontecha, J., M. Kalab, J. A. Medina, C. Pelaez, and M. Juarez. 1996 Effects of freezing and frozen storage on the microstructure and texture of ewe's milk cheese. Zeitschrift fur Lebensmittel Untersuchung und Forschung. 203:245-251.

Harvey, C. D., H. A. Morris, and R. Jenness. 1982. Relation between melting and textural properties of process Cheddar cheese. J. Dairy Sci. 65:2291-2295.

Johnson, M. E., and N. F. Olson. 1985. A comparison of available methods for determining salt levels in cheese. J. Dairy Sci. 68:1020-1024.

Kasprzak, K. 1992. The effect of fat, moisture, and salt on the freezing qualities of Cheddar-type cheeses. M.S. Thesis, Univ. of Wisconsin-Madison, Madison, WI.

Keller, B., N. F. Olson, and T. Richardson. 1974. Mineral retention and rheological properties of Mozzarella cheese made by direct acidification. J. Dairy Sci. 57:174-180.

Kuo, M.-I., Y.-C. Wang, and S. Gunasekaran. 2000. A viscoelasticity index for cheese meltability evaluation. J. Dairy Sci. 83:412-417.

Kuo, M.-I., S. Gunasekaran, M. Johnson, and C. Chen. 2001. Nuclear magnetic resonance study of water mobility in pasta filata and nonpasta filata Mozzarella. J. Dairy Sci. 84:1950-1958.

Kuo, M.-I. 2001. Distribution and mobility of water in pasta filata and nonpasta filata Mozzarella cheeses. Ph.D. Diss., Univ. Wisconsin, Madison.

Luck, H. 1977. Preservation of cheese and perishable dairy products by freezing. S. Afr. J. Dairy Technol. 9:127.

Marschoun, L. T., K. Muthukumarappan, and S. Gunasekaran. 2001. Thermal properties of Cheddar cheese: Experimental and modeling. Int. J. Food Properties 4:205-225.

McDowall, F. H. 1938. Storage of cheese at freezing temperatures. New Zealand J. Sci. Technol. 20:31A.

McMahon, D. J., R. L. Fife, and C. J. Oberg. 1999. Water partitioning in Mozzarella cheese and its relationship to cheese meltability. J. Dairy Sci. 82:1361-1369.

Morris, H. A., and W. B. Combs. 1955. Cheese you can freeze. Milk Prod. J. 46:12-13.

Oberg, C. J., R. K. Merrill, L. V. Moyes, R. J. Brown, and G. H. Richardson. 1991a. Effects of Lactobacillus helveticus culture on physical properties of Mozzarella cheese. J. Dairy Sci. 74:4101-4107.

Oberg, C. J., A. Wang, L. V. Moyes, R. J. Brown, and G. H. Richardson. 1991b. Effects of proteolysis activity of thermolactic cultures on physical properties of Mozzarella cheese. J. Dairy Sci. 74:389-397.

Oberg, C. J., R. K. Merrill, R. J. Brown, and G. H. Richardson. 1992a. Effects of milk-clotting enzymes on physical properties of Mozzarella cheese. J. Dairy Sci. 75:669-675.

Oberg, C. J., R. K. Merrill, R. J. Brown, and G. H. Richardson. 1992b. Effects of freezing, thawing, and shredding on low moisture, part-skim Mozzarella cheese. J. Dairy Sci. 75:1161-1166.

Perez-Munuera, I., M. Estevez, and M. A. Lluch. 1999. Note. Study of some typical Spanish cheeses by scanning electron microscopy. Main microstructural modifications caused by freezing. Food Sci. Technol. Int. 5:515-521. 
Price, W. V. 1935. Packaging American cheese. Wisconsin Agric. Exp. Stn. Bull. 130, Madison, WI.

Shannon, C. W. 1974. The effects of freezing Cheddar cheese on certain physical characteristics and the survival of some microorganisms. Ph.D. Diss., Mississippi State Univ., Mississippi State.

Sommer, H. H. 1928. The freezing point of Cheddar cheese: Injury of cheese by freezing. J. Dairy Sci. 11:9-17.

Tunick, M. H., E. L. Malin, P. W. Smith, J. J. Shieh, B. C. Sullivan, K. L. Mackey, and V. H. Holsinger. 1993. Proteolysis and rheology of low fat and full fat Mozzarella cheeses prepared from homogenized milk. J. Dairy Sci. 76:3621-3628.

Tunick, M. H., and J. J. Shieh. 1995. Rheology of reduced fat Mozzarella cheese. Pages 7-19 in Chemistry of Structure-Function Relationships in Cheese. E. L. Malin and M. H. Tunick, ed. Plenum Press, New York, NY.

Wang, Y.-C., K. Muthukumarappan, M. M. Ak, and S. Gunasekaran. 1998. A device for evaluating melt/flow characteristics of cheeses. J. Texture Stud. 29:43-55. 